\title{
EFFECT OF BUSINESS STRATEGY AND PROFIT MANAGEMENT OF COMPANY PERFORMANCE (Case Study on Manufacturing Companies in the Consumer Goods Industry Sector on the Indonesia Stock Exchange 2013-2016)
}

\author{
Wieta Chairunesia \\ Accounting Study Program, \\ Faculty of Economics and Business, \\ Universitas Mercu Buana \\ Molina \\ Accounting Study Program, \\ Faculty of Economics and Business, \\ Universitas Nasional Jakarta
}

\author{
Rista Bintara \\ Accounting Study Program, \\ Faculty of Economics and Business, \\ Universitas Mercu Buana
}

\author{
Bambang Subiyanto \\ Accounting Study Program, \\ Faculty of Economics and Business, \\ Universitas Nasional Jakarta
}

Article DOI: https://doi.org/10.36713/epra3889

\section{ABSTRACT}

The purpose of this study was to determine the effect of Business Strategy, Profit Management and Good Corporate Governance Mechanisms on Financial Performance This study used manufacturing companies in the consumer goods industry sector which were listed on the Indonesia Stock Exchange during 2013-2016.

This research is a quantitative study that analyzes the Effect of Business Strategy, Profit Management and Good Corporate Governance Mechanisms on Financial Performance. This research uses multiple regression analysis methods. A good business strategy by suppressing earnings management activities through the mechanism of Good Corporate Governance is expected to improve company performance.

The results of this study indicate that (1) the Business Strategy which is proxied by Low Cost and the mechanism of Good Corporate Governance which is proxied by the Independent Board of Commissioners has a significant positive effect on company performance, (2) the mechanism of Good Corporate Governance which is proxied by the Independent Board of Commissioners has a significant negative effect on company performance, (3) Profit Management and Good Corporate Governance mechanisms that are proxied by the Audit Committee have no effect on company performance.

KEYWORDS: Business Strategy, Company Performance, Earnings Management, Good Corporate Governance Mechanism.

\section{PRELIMINARY}

The company in its development is always trying to maintain its business excellence in improving company performance. Strategy formulation is the process of deciding organizational goals and strategies to achieve goals. The strategy is a big and important plan. The strategy sets, in general, the direction of organizational movement desired by senior management. The need to formulate a strategy usually arises in response to threats received, for example, attacks from competitors, shifts in consumer tastes or new government regulations or from opportunities such as innovation, new technological perceptions of customer behavior, or the development of new applications of existing products (Anthony \& Govidarajan, 2005).

Accounting information relating to the company's operational activities is the most basic requirement in the decision-making process for the owner and management of the company, one source of that information is the financial statements. Therefore, for decision making to be proven based on the financial statements presented by management, the information submitted must be relevant and reliable. The information provided to the owner by management may not guarantee that the information reflects the company's actual financial condition.

The management has different interests with the owner of the company. The owner of the company as 
the owner of capital wants management to guarantee their interests and an increase in profits as an indication of the return of capital that has been invested, while management wants a good performance appraisal that is indicated by the acquisition of profits that continue to increase so as to increase their incentives. One of the things that management has done to influence the earnings figures of the companies it manages, management is through earnings management. Earnings management is done by playing with the accrual components in the financial statements because the accrual component can be played with numbers through the accounting method that is used in accordance with the wishes of people who take notes and prepare financial statements (Sulistyanto, 2014).

Management actions to conduct earnings management will reduce the reliability of reported earnings (Scott, 2006), thereby reducing earnings quality because the reported earnings information does not indicate actual economic reliability.

Good financial performance shows that the company's financial statements are reported in accordance with applicable accounting standards, namely PSAK. But in reality, there are still companies that report their financial statements with truthful information. According to Widyatama \& Wibowo (2015) in companies with poor governance, there can be a mismatch between the information in the financial statements and the conditions on the ground in the company.

The mechanism that can be done to overcome this problem is by implementing good corporate governance. Good Corporate Governance (GCG) is a form of good corporate management. A good corporate governance mechanism will provide protection to shareholders and directors to recover the investment in a fair, appropriate and efficient manner and ensure that management acts as best as it can in the interests of the company (Hidayah, 2016).

Research conducted by the authors is a combination of Santoso, et al (2017) that earnings management has a positive but not significant effect on company performance. In contrast to Haryanto and Rahman (2013) in the study of the influence of business strategies on inventory management and company performance with the results, there is a positive and significant relationship between inventory systems and company performance and it is evident that the business strategy influences the relationship of the inventory system with company performance.

\section{FORMULATION OF THE PROBLEM}

Based on the background that has been explained, the formulation of the problems of this study include:

a. Does business strategy influence financial performance? b. Does good corporate governance affect the company's performance?

c. Does earnings management affect the company's performance?

\section{LITERATURE REVIEW, THEORETICAL FRAMEWORK, HYPOTHESIS \\ Agency Theory}

In the agency theory proposed by Jensen and Meckling (1976) the separation between the owner and manager of the company can cause agency problems between the owner (principal) and management (agent). Agency problems can be caused by differences in interests between owners and management. These differences in interests have caused problems in the future. To be able to overcome this, management as the manager of the company is expected to be more transparent in disclosing the company's financial information so that it can help in making decisions by interested parties (stakeholders) including the company owner.

\section{Company performance}

Company Performance Financial performance according to Rudianto (2013: 189) is the result or presentation that has been achieved by management in carrying out its function of managing company assets effectively over a certain period.

Jumingan (2011: 2) states that financial performance is a picture of financial conditions in a particular period both regarding aspects of raising funds and channeling funds which are usually measured by indicators of capital adequacy, liquidity, and profitability.

According to Fahmi (2012: 2) that financial performance is an analysis conducted using the rules of financial implementation properly and correctly. Measurement of company performance using Return On Assets which is an approach that is often used to measure the rate of return on assets (Prasetya et al, 2017) with the following formula:

$$
R O A=\frac{\text { Earnings After Tax }}{\text { Total Asset }}
$$

\section{Business strategy}

Research Porter (1985) developed a framework that maps the way companies have the right business strategy in order to compete effectively. Argues that a company must choose between competing as the lowest cost producer in their respective industries (cost leadership strategy) or competing by producing products that are in terms of quality, physical characteristics or special service (product differentiation strategy).

Porter (1996) emphasizes that the sensibility of a company's strategy is its ability to deliberately choose a series of activities that will produce a unique value for its customers. Low-cost strategy as 
measured by the dimensions of asset utilization efficiency and differentiation as measured by price premium capability as conducted by Haryanto \& Rahman's (2013) research which refers to previous research (Gani and Jermias, 2006).

Measurement of business strategies can be used with 12 indicators, researchers take a low-cost strategy (low cost) which is formulated as follows (Haryanto and Rahman, 2013):

$$
\text { Asset Utilization Efficiency }=\frac{\text { Sales }}{\text { Total Asset }}
$$

\section{Earnings Management}

Earnings management is the actions taken by company management to influence reported earnings. The purpose of earnings management is to improve the welfare of certain parties (agents), although in the long run there is no difference in the company's cumulative profit with earnings that can be identified as a profit (Darwis, 2012).

Scott (in Herawaty (2008) explains that managers have the flexibility to choose several alternatives in recording transactions while choosing options in accounting treatment. This flexibility is used by company management to manage earnings. Management behavior that underlies the birth of earnings management is opportunistic behavior manager and efficient contracting As an opportunistic behavior, managers maximize their utility in dealing with compensation and debt contracts and political costs.

Measure and calculate accrual earnings management using the revenue discretionary model approach (Stubben, 2010). With the following formula:

$$
\begin{aligned}
\Delta \text { ARit }= & \alpha+\beta 1 \Delta \text { Rit }+\beta 2 \Delta \text { Rit x SIZEit }+\beta 3 \Delta \text { Rit } \\
& \text { xAGEit }+\beta 4 \Delta \text { Rit xAGE_SQit }+\beta 5 \Delta \text { Rit } \\
& \text { x GRMit }+\beta 6 \Delta \text { Rit xGRM_SQit }+ \text { e }
\end{aligned}
$$

Note: $A R=$ year-end receivables, $\mathrm{R} 1 \_3=$ revenue in the first three quarters, SIZE $=$ natural $\log$ of total year-end assets, AGE = company age, GRM = Gross margin, $\mathrm{SQ}=$ variable squared and $\mathrm{e}=$ error.

\section{Good Corporate Governance}

Corporate Governance is a system that regulates and controls companies that are expected to provide and enhance corporate value to shareholders (Herawaty, 2008). Kamil \& Hapsari (2014) explained that the essence of corporate governance is improving company performance through monitoring management performance and the existence of management accountability to stakeholders and other stakeholders based on applicable rules and regulations.

Shleifer and Vishny (in Herawaty, 2008) stated that corporate governance is a way or mechanism to provide confidence to suppliers of corporate funds that they will get a return on their investment.
In its application, according to Sutedi (2012), Corporate Governance has several mechanisms, namely external and internal mechanisms. The external mechanism is influenced by the company's external factors including investors, public accountants, lenders and institutions that certify legality. While internal mechanisms are influenced by internal factors including institutional ownership, managerial ownership, the board of independent commissioners and the audit committee.

\section{Managerial Ownership}

Sutedi (2012) explained that managerial ownership is the number of shares owned by company management. The presence of managerial shares (insider ownership) can be used to reduce agency costs that have the potential to arise because by owning company shares, managers are expected to feel directly the benefits of each decision they make (Riana \& Iskandar, 2017). According to Hartono \& Nugrahanti (2014) with the ownership of management shares, then management will also benefit directly from the decisions it makes, but will also bear the risk directly if the decision is wrong.

According to Ross, et al (1999) (in Hartono \& Nugrahanti, 2014) states that the greater the proportion of management ownership in a company, then more management tends to try harder for the interests of shareholders who are none other than themselves. Thus the existence of Managerial Ownership can motivate management to improve company performance. Managerial ownership is formulated as follows (Kamil \& Hapsari, 2014):

$$
\mathrm{KM}=\frac{\text { Number of shares owned by management }}{\text { Number of Shares Outstanding }}
$$

\section{Independent Board of Commissioners}

Based on Law No. 40 of 2007 concerning Limited Liability Companies, the board of commissioners is the party in charge of overseeing the management policies, the course of management in general, both regarding the company and the company's business, and giving advice to directors. An independent commissioner is a party that has no affiliate relationship with a company and understands the laws and regulations in the capital market (Decree of the Directors of PT. Jakarta Stock Exchange No. Kep-315 / BEJ / 062000).

An independent commissioner is the best position to carry out the monitoring function in order to create a company with good corporate governance. In general, independent boards of commissioners have better supervision of managers so that they are able to influence the possibility of irregularities by managers (Nabila \& Daljono, 2013). This is consistent with the opinion of Jensen \& Meckling (1976) which states that agency theory supports the statement that to increase the independence of the board, the board 
must be dominated by parties from outside the company (outsider). The Independent Board of Commissioners is formulated as follows (Kamil \& Hapsari, 2014):

$$
\begin{aligned}
& \text { DKI } \\
& =\frac{\text { Number of Independent Commissioners }}{\text { Total Members of the Board of Commissioners }}
\end{aligned}
$$

\section{Audit Committee}

The Audit Committee was formed as an internal control effort on management activities including to reduce the occurrence of earnings management. In order for internal control to run well, it is expected that the Audit Committee will improve its monitoring function on management by conducting regular Audit Committee meetings. Based on the Guidelines for the Establishment of the Audit Committee (FCGI, 2002), the Audit Committee must hold meetings at least every three months or four times during one year. With increasingly stringent supervision, management will lose the opportunity to take fraudulent actions related to financial statements (Nabila \& Daljono, 2013). Thus the Audit Committee in this research was measured through the number of Audit Committee meetings in one period (Perdana et al, 2014)

\section{Theoretical Framework}

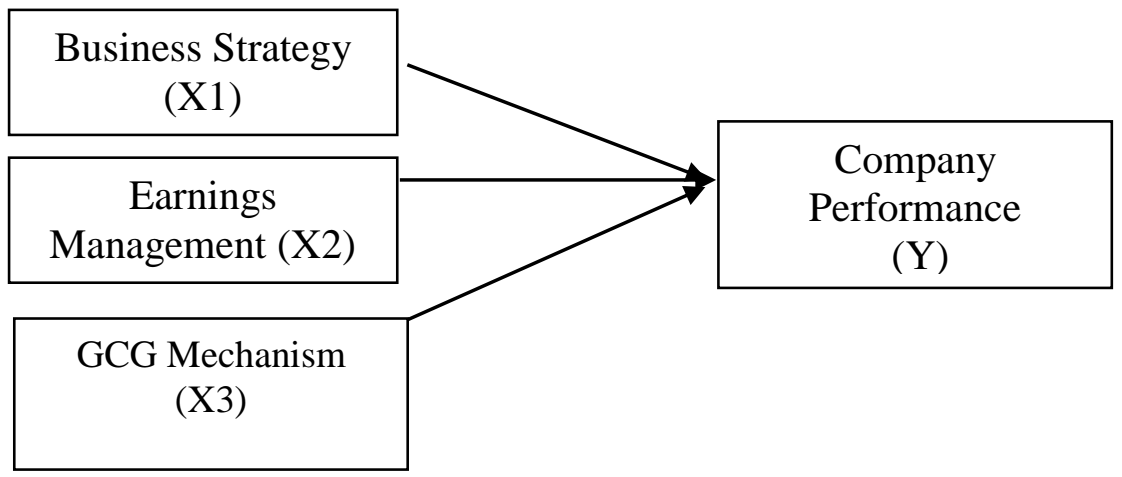

Gambar 1.

Rerangka Pemikiran

\section{HYPOTHESIS}

Based on the theory and background of the problem, the formulation of the problem, the purpose of the study as described above, the hypotheses proposed in this study are as follows:

H1: Business strategy with low cost has a positive effect on company performance

$\mathrm{H} 2$ : Earnings management affects company performance.

H3a: Independent Board of Commissioners has a positive effect on Company Performance

H3b: Managerial Ownership has a positive effect on Company Performance

H3c: The number of audit committee meetings has a positive effect on Company Performance

\section{RESEARCH METHODS}

This research was conducted in manufacturing companies in the consumer goods industry sector which were listed on the Indonesia Stock Exchange during 2013-2016 Data obtained were obtained from the official website of the IDX (web.idx.id).

This research is quantitative research. Taking research samples using a purposive sampling technique where there are certain criteria. In order to obtain a sample of 15 companies with a total of 4 data year so that it becomes 60 samples.

This study uses secondary data on financial information and annual reports of manufacturing companies for the period 2013-2016 which are listed on the Indonesia Stock Exchange (web..idx.id).

This study uses multiple regression analysis methods with the classic assumption test that is a prerequisite in the model. Before multiple regression analysis is used to test hypotheses, classical assumptions are tested first.

The regression equation proposed in this study is as follows:

$$
\begin{gathered}
\mathrm{KP}=\alpha+\beta 2 \mathrm{SB}+\beta 3 \mathrm{ML}+\beta 4 \mathrm{DKI}+\beta 5 \mathrm{KM}+\beta 4 \\
\mathrm{RKA}+\mathrm{e} 2
\end{gathered}
$$

Note: $\alpha=$ constant, $\mathrm{SB}=$ Business Strategy, $\mathrm{ML}=$ Profit Management, DKI = Independent Board of Commissioners, $\mathrm{KM}=$ Managerial Ownership, RKA $=$ Audit Committee Meeting and $\mathrm{KP}=$ Company performance. 


\section{RESULTS AND DISCUSSION \\ Descriptive Analysis}

Table 2

Descriptive Statistics

\begin{tabular}{|l|l|l|l|l|l|}
\hline & $\mathrm{N}$ & Minimum & Maximum & Mean & Std. Deviation \\
\hline SB_LCost & 60 & .70 & 2.84 & 1.3500 & .47626 \\
EM & 60 & .00 & .55 & .0324 & .07271 \\
DKI & 60 & .20 & 1.50 & .4172 & .16745 \\
KM & 60 & .00 & .23 & .0163 & .05785 \\
KA & 60 & 3.00 & 4.00 & 3.1667 & .37582 \\
KP & 60 & .02 & .66 & .1353 & .11982 \\
Valid N (listwise) & 60 & & & & \\
\hline
\end{tabular}

The table shows the amount of data in the study were 60 data samples. From the results of descriptive statistical tests, information is obtained that the Business Strategy variable has a range of values from 0.70 to 2.84 which is the lowest value of PT Indofood Sukses Makmur Tbk in 2015 and the highest value of PT Hanjaya Mandala Sampoerna Tbk in 2014. The average value The average Business Strategy is 1.3500 and the standard deviation is 0.57626 . This means that the data distribution is not too varied, the data is good enough to be used in the regression test, because the data distribution is close to the average value.

Earnings Management Variables range in value from 0.00 to 0.55 which is the lowest value, namely PT Indofood Sukses Makmur Tbk in 2015 and the highest value, PT Multi Bintang Indonesia Tbk in 2013. The average value of Profit Management is 0.0324 and a standard deviation of 0.07271 . This means that the data distribution is not too varied, the data is good enough to be used in the regression test, because the data distribution is close to the average value.

The variable Independent Board of Commissioners has a range of values from 0.20 to 1.50 which is the lowest value, namely PT Kimia Farma Tbk in 2016 and the highest value, namely PT Multi Bintang Indonesia Tbk in 2016. The average value of the Independent Board of Commissioners is 0.4172 and the standard deviation of 0.16745 . This means that the data distribution is not too varied, the data is good enough to be used in the regression test, because the data distribution is close to the average value.

Managerial Ownership Variables range in value from 0.00 to 0.23 . The lowest value of 0.00 is due to the absence of Managerial Ownership in PT Akasha Wira International Tbk, PT Delta Djakarta Tbk, PT Darya-Varia Laboratoria Tbk, PT Hanjaya Mandala Sampoerna Tbk, PT Indofood Sukses Makmur Tbk, PT Multi Bintang Indonesia Tbk, and PT Nippon Indosari Corporindo Tbk in the span of
2013-2016. The highest value is shown by the Manager's Ownership in PT Pyridam Farma Tbk during 2013-2016. The average value of Managerial Ownership is 0.0163 and the standard deviation is 0.05785 . This means that the data distribution is not too varied, the data is good enough to be used in the regression test, because the data distribution is close to the average value.

The Audit Committee variable has a range of values from 3 to 4 . The average value of the Audit Committee is 3.1667 and the standard deviation is 0.37582 . This means that the data distribution is not too varied, the data is good enough to be used in the regression test, because the data distribution is close to the average value.

Company Performance Variables range in value from 0.02 to 0.66 , which is the lowest value, namely PT Pyridam Farma Tbk in 2014 \& 2015 and the highest value, PT Multi Bintang Indonesia Tbk in 2013. The average value of Company Performance is 0,1353 and the standard deviation of 0.11982 . This means that the data distribution is not too varied, the data is good enough to be used in the regression test, because the data distribution is close to the average value.

\section{Classical Assumption Testing 1. Normality Test Results}

The statistical test used to test residual normality can be detected by the KolmogorovSmirnov test. With the results of the KolmogorovSmirnov $Z$ value of 0.094 and a significant probability level of 0.200 . Because of the Asymp probability value. Sig (2-tailed) is greater than the significant level of 0.05 , it can be concluded that the data in the regression model are normally distributed.

\section{Multicollinearity Test Results}

From the data table, there were no symptoms of multicollinearity, because of the tolerance value $>0.1$ and the VIF value $<10$ 
Table 3.

Multicollinearity Results

\begin{tabular}{|ll|c|c|}
\hline \multirow{2}{*}{ Model } & \multicolumn{2}{|c|}{ Collinearity Statistics } \\
\cline { 3 - 4 } & & Tolerance & VIF \\
\hline 1 & (Constant) & & \\
& SB_LCost & .932 & 1.073 \\
& EM & .962 & 1.039 \\
& DKI & .977 & 1.023 \\
& KM & .995 & 1.005 \\
KA & .953 & 1.049 \\
\hline
\end{tabular}

a. Dependent Variable: KP

b.

From the above results, it can be seen that the variance inflation factor (VIF) value of the five variables (Business Strategy, Profit Management, Independent Board of Commissioners, Managerial Ownership, and Audit Committee) is smaller than 10, and the tolerance value is above 0.10 so that it can it is assumed that independent variables do not occur multicollinearity.

\section{Autocorrelation Test Results}

Based on table 4.4 above shows the value of Durbin - Watson is 1,060 . The $\mathrm{D}-\mathrm{W}$ value is compared with the D-W table value. D-W tables were obtained using a sample benchmark of 60 and the number of independent variables with a confidence level of 5\%. By using this benchmark, the lower limit value $(\mathrm{dl})=1.4797$ and the upper limit $(\mathrm{du})=1.6889$ are obtained. There is no autocorrelation if the $\mathrm{D}-\mathrm{W}$ value is above $(\mathrm{du})=$ 1.6889 and $(4-\mathrm{du})=2.3111$.

Table 4

Autocorrelation Test Results Model Summaryb

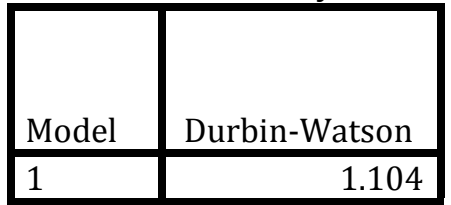

a. Predictors: (Constant), KA, KM, KI, EM, SB_LCost

b. Dependent Variable: KP

\section{Heteroscedasticity Test Results}

Tabel 5

Heteroscedasticity Test Results Coefficients $^{\mathbf{a}}$

\begin{tabular}{|c|c|c|c|c|c|c|}
\hline \multirow{2}{*}{\multicolumn{2}{|c|}{ Model }} & \multicolumn{2}{|c|}{ Unstandardized Coefficients } & \multirow{2}{*}{$\begin{array}{c}\text { Standardized } \\
\text { Coefficients } \\
\text { Beta }\end{array}$} & \multirow[b]{2}{*}{$\mathrm{t}$} & \multirow[b]{2}{*}{ Sig. } \\
\hline & & B & Std. Error & & & \\
\hline \multirow[t]{6}{*}{1} & (Constant) & -11.781 & 6.052 & & -1.947 & .062 \\
\hline & Ln_X1 & 3.689 & 2.150 & .319 & 1.716 & .098 \\
\hline & Ln_X2 & .577 & .432 & .254 & 1.336 & .193 \\
\hline & Ln_X3 & .090 & 2.111 & .007 & .043 & .966 \\
\hline & Ln_X4 & -.290 & .192 & -.252 & -1.511 & .143 \\
\hline & Ln_X5 & 3.963 & 4.261 & .150 & .930 & .361 \\
\hline
\end{tabular}

a. Dependent Variable: LN_Res1 
The results of this test indicate that all significance values of each test showed $\mathrm{Sig}>0.05$, so it was concluded between LN Res1 with Ln_X1, Ln_X2, Ln_X3, Ln_X4, and Ln_X5 there were no symptoms of heteroscedasticity.

\section{Multiple Regression Analysis}

Then an analysis is conducted to determine the effect of the independent variables, namely: Business strategy with low-cost proxy (X1), Profit
Management (X2), Independent Board of Commissioners (X3a), Managerial Ownership (X3b) and Audit Committee (X3c).

Based on the calculation results of the multiple linear regression equation as follows:

$\mathrm{Y}=-0,186+0.1136 \mathrm{SB}$ LCost $+0.867 \mathrm{EM}+$ $0.208 \mathrm{DKI}-0.461 \mathrm{KM}+0.019 \mathrm{KA}$

\section{Model Feasibility Test (Coefficient of Determination)}

Table 6

Coefficient of Determination Test Result Model Summaryb

\begin{tabular}{|l|c|r|r|r|}
\hline Model & $\mathrm{R}$ & R Square & \multicolumn{1}{|c|}{$\begin{array}{c}\text { Adjusted R } \\
\text { Square }\end{array}$} & $\begin{array}{c}\text { Std. Error of } \\
\text { the Estimate }\end{array}$ \\
\hline 1 & $.864^{\mathrm{a}}$ & .747 & .724 & .06300 \\
\hline
\end{tabular}

a. Predictors: (Constant), KA, KM, KI, EM, SB_LCost

b. Dependent Variable: KP

Based on the table above, the value of R2 shows the value of 0.747 or $74.7 \%$. This means that in this model the percentage contribution to the influence of the business strategy, profit management. The Independent Board of Commissioners, Managerial Ownership, and Audit Committee on the Company's Performance is quite large, namely $74.7 \%$. Or a variable variation of the business strategy, Profit Management. The Independent Board of Commissioners, Managerial Ownership, and Audit Committee are able to explain the model of $74.7 \%$ of the variation in the Company's Value variable. While the remaining $25.3 \%$ can be explained by other variables not included in this study. Then this model deserves further testing.

\section{Hypothesis Testing \\ 1. Simultaneous Test (F-Test)}

Based on the F-test results obtained Sig of 0,000 $<0.05$ then Ho is rejected. This means that it can be concluded that there is a significant influence between Business Strategy, Profit Management, Independent Board of Commissioners, Managerial Ownership, and the Audit Committee together on Company Performance. Thus, the resulting regression model deserves to be analyzed.

\section{Partial Test (T-Test)}

Table 7

Partial Test Result (T-Test) Coefficients ${ }^{\mathrm{a}}$

\begin{tabular}{|c|c|c|c|c|c|c|}
\hline \multirow{2}{*}{\multicolumn{2}{|c|}{ Model }} & \multicolumn{2}{|c|}{ Unstandardized Coefficients } & \multirow{2}{*}{$\begin{array}{c}\text { Standardized } \\
\text { Coefficients } \\
\text { Beta }\end{array}$} & \multirow[b]{2}{*}{$\mathrm{t}$} & \multirow[b]{2}{*}{ Sig. } \\
\hline & & $\mathrm{B}$ & Std. Error & & & \\
\hline \multirow[t]{6}{*}{1} & (Constant) & -.186 & .082 & & -2.278 & .027 \\
\hline & SB_LCost & .113 & .018 & .451 & 6.359 & .000 \\
\hline & EM & .867 & .115 & .526 & 7.540 & .000 \\
\hline & $\mathrm{KI}$ & .208 & .050 & .290 & 4.190 & .000 \\
\hline & KM & -.461 & .142 & -.223 & -3.243 & .002 \\
\hline & KA & .019 & .022 & .061 & .868 & .389 \\
\hline
\end{tabular}

a. Dependent Variable: KP 
a. The Influence of Low Cost (LC) Business Strategy on Company Performance

Business Strategy which is proxied by Low Cost has a significance value of Sig (0.00) $<0.05$ meaning that there is a partially significant influence between Business Strategy and Company Performance. So from this case, it can be concluded that Business Strategy partially has a significant effect on Company Performance.

Companies that have overall cost advantages can take advantage of their advantages to set low costs or take lower profit margins and sell at prices that can provide greater profits than competitors, thus profits can be used to improve the quality and efficiency of the company so that it can affect both the performance company.

The results of the study are in line with research conducted by (Izzati, 2016) testing the effect of business strategy on earnings management as the company's performance as an intervening variable. The results of the analysis show that business strategy influences company performance.

\section{b. Effect of Profit Management on Company Performance}

Earnings management has a significance value $(0,000)<0.05$ meaning that there is a partially significant influence between earnings management and company performance. So from this case, it can be concluded that partially earnings management has a significant effect on company performance.

The results of this study indicate that earnings management practices have a significant positive effect on company performance because it is indicated that earnings management practiced has a direct impact on earnings so that company performance looks good. This is contrary to the study of Santoso, et al (2017) that earnings management has no effect on company performance.

\section{c. Influence of Independent Board of Commissioners on Company Performance}

The Independent Board of Commissioners has a significance value $(0,000)<0.05$ meaning that there is a partially significant influence between the Independent Board of Commissioners and the Company's performance. So it can be concluded that partially the Independent Board of Commissioners has a significant effect on Company Performance.

Herawaty (2008) in her research stated that if a company has an independent commissioner, the financial statements presented by management tend to have more integrity because in the company there are bodies that oversee and protect the rights of parties outside the company's management. The greater the proportion of the independent board of commissioners is expected to increase supervision of the manager's performance which is expected to improve company performance.

The results of this study indicate that the independent board of commissioners has a significant positive effect on company performance. Thus the results of this study are in line with the results of the study of Widyatama and Wibowo (2015).

d. Effect of Managerial Ownership on Company Performance

Managerial Ownership has a significance value $(0.002)<0.05$ meaning that partially there is a significant influence between Managerial Ownership with Company Performance. Then it can be concluded that partially Managerial Ownership has a significant effect on Company Performance.

Good company performance can have a positive impact on shareholders. So it is fitting for managers to make full effort to improve company performance. As stated by Ross, et al (1999) (in Hartono \& Nugrahanti, 2014) that the greater the proportion of management ownership in a company, then management tends to try harder for the interests of shareholders who are none other than themselves. However, the results of this study actually contradict the statement, which is a significant negative effect which means that every time there is an increase in Managerial Ownership, the variable Company Performance will decrease.

\section{e. The Influence of the Audit Committee on Company Performance}

The Audit Committee has a significance value $(0.389)>0.05$ meaning that there is no significant partial effect between the Audit Committee and Company Performance. So it can be 
concluded that partially the Audit Committee has no significant effect on Company Performance.

The more often the audit committee meets, the higher the level of supervision of management. With the high level of audit committee oversight of management, it can improve financial performance.

However, the results of this study are not in accordance with the hypotheses that have been formulated which show that the number of audit committee meetings has no significant effect on company performance. The results of this study also corroborated the results of Widyatama and Wibowo's (2015) research which also showed that the number of audit committee meetings had no effect on the company's financial performance.

\section{CONCLUSIONS AND SUGGESTIONS Conclusions}

Based on the results of testing and discussion of the influence of business strategy, earnings management and Good Corporate Governance mechanisms on company performance can be concluded as follows:

1. Business Strategy which is proxied by Low Cost has a significant positive effect on company performance.

2. Profit Management has no effect on company performance.

3. The mechanism of Good Corporate Governance proxied by the Independent Board of Commissioners has a significant positive effect on company performance.

4. The mechanism of Good Corporate Governance proxied by Managerial Ownership has a significant negative effect on company performance.

5. The mechanism of Good Corporate Governance proxied by the Audit Committee has no effect on company performance.

\section{Suggestions}

1. Future studies are expected to expand the population and the research sample is not only limited to manufacturing sector manufacturing companies listed on the Indonesia Stock Exchange but also to expand the scope of the research sample to other types of companies such as banking, mining, plantations, insurance companies and so on.

2. Future studies are expected to be able to use components that affect company performance such as leverage, company size, capital structure and others.

3. This study only limited the observation time to 4 years, namely 2013-2016. If the time used is longer or using different observations it should be recommended to add years of observation.

\section{REFERENCES}

1. Anthony dan Govindarajan. 2005. Management Control System, Salemba Empat. Jakarta

2. Brigita, W., \& Adiwibowo, A. S. (2017). Pengaruh Strategi Tingkat Bisnis, Persaingan Pasar, dan Leverage terhadap Manajemen Laba. Diponegoro Journal of Accounting, 6(4), 1-13.

3. Bursa dan Valas. 2017. Saham Toshiba Anjlok 12\%. dibuka tanggal 12 April 2018. https://finance.detik.com/bursa-danvalas/d-3423138/saham-toshiba-anjlok-12

4. Fahmi, Irham. 2012. Analisis Laporan Keuangan. Bandung. Alfabeta.

5. FCGI. (2002). Pedoman Pembentukan Komite Audit yang Efektif. Jakarta: Komite Nasional Kebijakan Governace Indonesia.

6. Fitriyani, dkk. 2012. Jurnal. Pengaruh Manajemen Laba Terhadap Kinerja Perusahaan dengan Kualitas Audit Sebagai Variabel Pemoderasi.

7. Ghozali, I. (2016). Desain Penelitian Kuantitatif dan Kualitatif untuk Akuntansi, Bisnis, dan ilmu Sosial Lainnya. Semarang: Yoga Pratama.

8. Haryanto, R., \& Rahman, A. (2013). Pengaruh Strategi Bisnis Terhadap Hubungan manajemen Persediaan dan kinerja Perusahaan (Studi Pada Perusahaan Publik di BEI). Jurnal Ekonomi \& Bisnis PNJ, 12(1).

9. Hidayah, N. (2016). Pengaruh Efektivitas Dewan Komisaris, Komite Audit Dan Sruktur Kepemilikan Terhadap Kualitas Audit Dan Manajemen Laba (Studi Pada Perusahaan Manufaktur yang Go Publik di BEI) (Doctoral dissertation, Fakultas Ekonomi UNISSULA).

10. Izzati, A. (2016). Pengaruh Strategi Bisnis Terhadap Manajemen Laba Dengan Kinerja Perusahaan Sebagai Variabel Intervening (Doctoral Dissertation, Universitas Airlangga).

11. Jensen, M. C., \& Meckling, W. H. (1976). Theory of The Firm: Managerial Behavior, Agency Costs and Ownership Structure. Journal of Financial Economics, 3, 305-360. https://doi.org/10.1016/0304405X(76)90026-X

12. Jumingan. (2011). Analisis Laporan Keuangan. Jakarta. Bumi Aksara.

13. Kamil, F., \& Hapsari, D. W. (2014). 
Pengaruh Manajemen Laba Terhadap Nilai Perusahaan Dengan Mekanisme Corporate Governance Sebagai Variabel Pemoderasi. In eProceedings of Management (pp. 1-24).

14. Perdana, Ramadhan Sukma., dan Raharja. (2014). Analisis Pengaruh Corporate Governance terhadap Nilai Perusahaan. Journal Of Accounting, Volume 3 No. 3. Hal 1-13. Semarang : Universitas Diponegoro.

15. Prasetya, W. S., \& Harjanto, S. (2017). Pengaruh Manajemen Laba Terhadap Kinerja Perusahaan Dengan Good Corporate Governance Sebagai Variabel Moderasi (Studi Kasus Pada Perusahaan Manufaktur Yang Terdaftar Di BEI Tahun 2011-2014). Jurnal Ekonomi Manajemen Akuntansi, 24(43).

16. Porter, M. E. (1985). Competitive Advantage: Creating and Sustaining Superior Performance. New York, NY: Free Press.

17. Porter, M. E. (1996). From competitive advantage to corporate strategy. Managing the multibusiness company. In M. Goold \& K. Luchs (Eds.), Strategic issues for diversified groups (pp. 285314). New York: Routledge.

18. Riana, \& Iskandar, D. (2017). Pengaruh Ukuran Perusahaan, Corporate Governance Dan Struktur Modal Terhadap Nilai Perusahaan ( Studi Empiris pada Perusahaan Pertambangan yang terdaftar di Bursa Efek Indonesia periode 2011 - 2014 ). PROFITA, 10(3), 409-425.

19. Rudianto. (2013). Akuntansi Manajemen Informasi Untuk Pengambilan Keputusan Strategis. Jakarta. Erlangga.

20. Santoso, A., Puspitasari, D., \& Widyaswati, R. (2017). Pengaruh Manajemen Laba Dan Ukuran Perusahaan Terhadap Kinerja Perusahaan Dengan Kualitas Audit Sebagai Variabel Pemoderasi (Studi Pada Perusahaan Manufaktur YangTerdaftar di BEI Periode 2011-2014). Jurnal Administrasi dan Bisnis (adbis), 11(1), 71 84.

21. Scott, William R. (2006). Financial Accounting Theory, Seventh Edition, Prentice-Hall, Toronto, Canada.

22. Stubben, S. R. (2010). Discretionary Revenues as a Measure of Earning Management. The Accounting Review Vol.85.No.2 pp.695-717.
23. Sulistyanto, Sri. 2014. Manajemen Laba Teori dan Model Empiris . PT. Grasindo. Jakarta

24. Sutedi, Adrian. 2012. Good Corporate Governance. Jakarta : Sinar Grafika.

25. Widyatama, B. D., \& Adiwibowo, A. S. (2015). Pengaruh Mekanisme Corporate Governance Terhadap Kinerja Keuangan. Doctoral dissertation, Fakultas Ekonomika dan Bisnis. 